\title{
Development and application of molecular typing methods for Salmonella spp - The UK experience
}

\author{
E.J. Threlfall
}

\begin{abstract}
Abstrak
Untuk usaha identifikasi dan penentuan tipe Salmonella, Laboratory of Enteric Pathogens menggunakan suatu kebijaksanaan hierarkis yang dimulai dengan subdivisi fenotipe, dan bilamana perlu dilengkapi dengan metoda berdasarkan analisis plasmid dan DNA kromosom (genotipe). Cara pemeriksaan plasmid termasuk tipe profil plasmid, sidik jari plasmid dan identifikasi gen-gen salmonella plasmid virulence (spv) yang mengandung plasmid. Pemeriksaan genotipe termasuk pemeriksaan ribotipe, pemeriksaan sidikjari dengan menyisipkan sekuen 200 (insertion sequence/IS) dan pulse field gel electrophoresis ( $P F G E$ ). Di samping memberikan gambaran sidik jari genotipe, PFGE juga dapat membantu pelacakan gen untuk menentukan urutan/sekuen spesifik dari DNA yang dianggap perlu, misalnya RNAr atau gen resistensi terhadap antibiotika. Selain hal tersebut telah dilakukan penelaahan aplikasi baru berbagai metoda $P C R$, termasuk rep-PCR, ERIC-PCR, dan RAP-D. Untuk penelitian resistensi antibiotika, metoda baru untuk pemetaan integron dengan $P C R$, yang dibantu dengan pemeriksaan sekuen secara langsung dari produk gen yang telah diamplifikasi, telah membantu membuka dimensi baru bagi pengetahuan kita tentang epidemiologi gen resistensi yang berlokasi di kromosom pada serotipe dan tipe faga yang penting. Keuntungan dan kelemahan dari pemeriksaan sidik jari genom akan dibicarakan, dengan referensi khusus pada KLB yang terjadi baru-baru ini, yang disebabkan oleh Salmonella agona, Salmonella anatum, dan kuman multiresisten S. typhimurium DT 104 (DT104). Sehubungan dengan DT 104, penggunaan analisis integron secara PCR untuk penelitian epidemiologi gen multiresistensi obat pada tipe faga ini juga akan dibicarakan.
\end{abstract}

\begin{abstract}
For the identification and typing of salmonellas the policy of the Laboratory of Enteric Pathogens is to use a hierarchical approach based in the first instance on phenotypic subdivion, supplemented when appropriate by methods based on the analysis of plasmid DNA and chromosomal DNA (genotyping). Plasmid DNA-based methods include plasmid profile typing, plasmid fingerprinting and the identification of plasmid-encoded salmonella plasmid virulence (spv) genes. Genotyping methods include ribotyping, insertion sequence (IS) 200 fingerprinting and pulsed-field gel electrophoresis ( $P F G E$ ). In addition to providing a genomic fingerprint PFGE can be used in conjunction with gene probing to locate specific DNA sequences of interest such as $r R N A$ or antibiotic resistance genes. More recently the applicability of a range of $P C R$-based methods including rep-PCR, ERIC-PCR and RAP-D have been assessed. For the investigation of antibiotic resistance recent advances in the PCR mapping of integrons coupled with direct sequencing of amplifield gene products has added a new dimension to our understanding of the epidemiology of chromosomally-located resistance genes in key serotypes and phage types. The strengths and weaknesses of genomic fingerprinting will be discussed with particular reference to recent international outbreaks of Salmonella agona, S. anatum and multiresistant S. typhimurium DT 104 (DT 104). In relation to DT 104, the use of integron analysis by PCR to investigate the epidemiology of multiple antibiotic resistance genes in this key phage type will also be discussed.
\end{abstract}

\section{INTRODUCTION}

In England and Wales salmonellosis accounts for about 30,000 reported infections per annum and is second only to campylobacteriosis as the most common cause of gastrointestinal disease at the present time1. To combat salmonellosis, laboratory-based surveillance of both human and animal infections is a necessary prerequisite of any intervention strategies. For this purpose detailed and reproducible methods of strain identification and typing are essen-

Laboratory of Enteric Pathogens,

Central Public Health Laboratory, 61 Colindale Avenue,

London NW9 SHT, UK tial. In the Laboratory of Enteric Pathogens (LEP), which is the national centre for salmonellas from humans in England and Wales, the policy is to use phenotypic methods - serotyping - for the primary identification of strains and phage typing and antibiogram analysis for subdividing of serotypes of clinical or epidemiological importance. For outbreak investigations these methods are supplemented by molecular methods based on analysis of plasmid DNA and chromosomal DNA (genotyping) ${ }^{2}$.

\section{PHENOTYPIC METHODS OF STRAIN IDEN- TIFICATION}

The genus Salmonella is defined as two taxons, namely Salmonella enterica and $S$. bongori of which 
the primary taxon, S. enterica, is divided into six subspecies on the basis of a range of biochemical reactions. Within subspecies, strains are classified into serotypes on the basis of diversity within the lipopolysaccharide $(\mathrm{O})$ and flagellar protein $(\mathrm{H})$ antigens and about 2200 such serotypes are now recognised 3 . Although the great majority of these are capable of causing disease in humans, in practice only a small number are important epidemiologically.

The primary phenotypic method for subdividing serotypes of clinical or epidemiological importance is phage typing and internationally accepted phage typing schemes have been developed for S. typhi, S. paratyphi A and B, S. enteritidis, $S$. typhimurium, $S$. virchow, S. hadar, S. pullorum and S. agona. Antibiogram analysis can prove a method for subdivision both within serotype and phage type and in the LEP all salmonellas are screened for resistance to a wide range of antimicrobial drugs ${ }^{4}$.

\section{DNA-BASED METHODS}

\section{Plasmid-based}

Methods based on the characterization of plasmid DNA include plasmid profile typing, plasmid fingerprinting and the identification of plasmid-mediated virulence genes. For a review of the application of plassmid-based methods to salmonella outbreaks in the UK, see Threlfall and Frost ${ }^{5}$.

\section{Genotyping}

Plasmid-based methods are applicable only to plasmid-carrying strains. More recent methods have sought to identify regions of heterogeneity within the bacterial chromosome (genotyping) and are applicable to both plasmid-carrying and plasmid-free strains. Such methods may be based on the identification of areas of heterogeneity using fragments (DNA probes) that will hybridise with complementary sequences in the target molecule following Southern blotting and DNA hybridisation (restriction fragment length polymorphism [RFLP] typing), or will seek to identify differences in patterns following the digestion of genomic DNA with restriction endonucleases, or will utilise the polymerase chain reaction (PCR) to amplify areas of DNA between known or arbitrarilygenerated sequences.

Methods utilising DNA hybridisation technology to detect variation in single or multicopy gene sequences across the bacterial genome include ribotyping, random cloned chromosomal sequence (RCCS) typing and insertion sequence (IS) 200 fingerprinting.

\section{Ribotyping}

Ribotyping is a form of RFLP analysis using DNA probes derived from ribosomal ribonucleic acid (rRNA). Initially used as a taxonomic tool, DNA fragments carrying rRNA genes were detected by hybridisation with an isotopically-labelled Escherichia coli $16+23 \mathrm{~S}$ rRNA probe 6 . More recently, plasmid pKK 3535 , which contains a rRNA gene operon, has been extensively used for ribotyping?. With the advent of gene sequencing and polymerase chain reaction-based methodology (PCR), highly specific probes have been constructed. In particular, an internal $550 \mathrm{bp}$ probe from the published sequence of the $16 \mathrm{~S}$ E. coli $r r n \mathrm{~B}$ gene has been used to provide a molecular fingerprint based on the distribution of conserved $16 \mathrm{~S} r \mathrm{rn}$ genes across the genome for several salmonella serotypes 8 .

\section{Random cloned chromosomal sequence (RCCS) typing}

Observations of heterogeneity in chromosomal restriction enzyme-generated fragment patterns can be enhanced by using randomly-cloned sequences of chromosomal DNA as single-stranded gene probes. This method of typing, which originally developed by Tompkins and co-workers 9 , provided a method for the differentiation of $S$. typhimurium but was of limited use for S. dublin and S. enteritidis. As yet, RCCS typing has not been fully evaluated for discrimination within phage type.

\section{Insertion sequence IS(200) fingerprinting}

Insertion sequences (ISs) are a special class of mobile genetic elements found in prokaryotic bacteria which contain only those genes necessary for their own transposition. For salmonellas, the Salmonella-specific 708 bp insertion sequence IS200 has been shown-to be distributed on conserved loci on the chromosome of many salmonella serotypes with copy numbers ranging from one to 2510 . In some serotypes identification of the number and distribution of IS200 elements in the genome has provided a method of discrimination suitable for epidemiological investigations ${ }^{11-13}$.

The main advantages of RFLP-based methods are that they can provide fingerprints which are easy to interpret and reproduce and for certain gene sequences, may provide information about strain phylogeny. Furthermore, the advent of gene sequencing 
and PCR has provided rapid methods of constructing highly specific gene probes based on published sequences, for example of the E. coli $r r n B$ gene or IS200. The main disadvantages are that the methods may be non-discriminatory. Furthermore, in the case of IS200 fingerprinting, not all serotypes or phage types possess such elements.

Methods based on restriction endonuclease analysis of genomic DNA followed by agarose gel electrophoresis

The method of DNA fingerprinting which is now most commonly used for the differentiation of salmonellas is pulsed-field gel electrophoresis (PFGE). PFGE is becoming increasingly used for the fingerprinting of Salmonella, and has been used for subdivision both within serotype ${ }^{14-16}$ and phage type 17-18.

\section{PCR-based methods}

PCR-based methods used for the fingerprinting of DNA in salmonella outbreaks include random amplified polymorphic DNA (RAPD) analysis (also called arbitrarily primed PCR [AP-PCR] ) and fingerprinting based on the presence of repetitive extragenic palindromic sequences (REPs), or enterobacterial repetitive intergenic consensus sequences (ERICs) in the bacterial genome.

\section{RAPD/AP-PCR typing}

RAPD /AP-PCR typing is based on the amplification of DNA fragments of unknown sequence following low stringency annealing of short $(10-20 \mathrm{bp})$ oligonucleotide primers. The resulting fragments are separated by conventional AGE to produce a characteristic fingerprint. For salmonellas, RAPD has been used for the differentiation of $S$. enteritidis ${ }^{19-21}$ and $S$. typhimurium 22 and more recently, for the differentiation of $S$. gold-coast in an outbreak situation in the UK (E J Threlfall, unpublished). RAPD fingerprinting has the advantage of rapidity but as yet the reproducibility is variable and the use of this method for outbreak investigations needs to be fully assessed.

\section{REP-PCR and ERIC-PCR}

Several families of short, repetitive DNA sequences have been identified in the bacterial genome, of which the best characterised are repetitive extragenic palindromic sequences (REPs), which are 38 bp long 23 and enterobacterial repetitive intergenic consensus sequences (ERICs), which are 22 bp long24. Primers based on REP and ERIC sequences can be used in the amplification of Salmonella DNA. The bands obtained after AGE of the PCR products (REPPCR, ERIC-PCR) represent amplification of DNA between adjacent repetitive sequences. For salmonellas, the use of these two methods is being evaluated in several laboratories. However in a recent comparative study of RAPD and ERIC-PCR for the discrimination of $S$. typhimurium and $S$. enteritidis, it was concluded that the potential of RAPD for strain discrimination was considerably greater than that offered by ERIC-PCR ${ }^{23}$.

\section{APPLICATION OF DNA-BASED METHODS TO OUTBREAK INVESTIGATIONS}

Since 1995 molecular typing using a combination of methods has been used in several international outbreaks. These include an outbreak of $S$. agona associated with a snack food prepared in Israel - PFGE 15, an outbreak of $S$. anatum associated with a formuladried milk product prepared in France - plasmid profile typing and PFGE 25 , and an extensive outbreak of $S$. gold-coast in the UK associated with home-produced cheese - IS200 fingerprinting RAPD \{unpublished\}. For investigations of multidrug-resistant $S$. typhimurium definitive phage type (DT 104) (currently second only to $S$. enteritidis phage type 4 in humans in England and Wales), the PCR mapping of integron-based antibiotic resistance genes coupled with direct sequencing of amplified gene products has provided a method of investigating the epidemiology of chromosomally-located resistance genes in this epidemic phage type.

\section{DISCUSSION}

One of the main advantages of DNA fingerprinting for subtyping of Salmonella is that the degree of discrimination can often be much greater than that achieved by phenotypic methods, and can reveal subtle differences in DNA structure which cannot be shown phenotypically. However as yet there are certain inherent limitations in DNA-based methodology. For example the choice of enzymes can give different results and it can be difficult to interpret the significance of small differences in molecular fingerprints. Furthermore, for some of the "new" methods of fingerprinting to be standardised and upgraded from in house "fingerprinting" to a general purpose typing scheme with defined reference strains, it is necessary to have access to a large and continually evolving data bank. It is also essential to have an agreed definition at an international level as to what constitutes a PFGE fingerprint", and what may be regarded as a variation within a fingerprint. 
For molecular typing schemes for Salmonella to be recognised internationally it is essential to have agreed standardisation of type nomenclature, methods, conditions and interpretation criteria, and even reference strains for designated molecular "types". For meaningful comparison of data, strict controls are essential. This is particularly important for PCR-based methods, in which there are inherent problems with reproducibility. As a consequence of this, although PCR-based methods may be used for "in house" typing, in general they are not as yet suitable for inter-laboratory studies. However standardisation in the design of thermocyclers coupled with improved protocols should result in methods such as RAPD and in particular, the new method of AFLP (amplified fragment length polymorphism) being increasingly used in salmonella epidemiology and becoming accepted methods for the subtyping and fingerprinting of salmonellas for outbreak investigations.

\section{REFERENCES}

1. Wall PG, de Louvois J, Gilbert RJ, Rowe B. Food poisoning: notifications, laboratory reports, and outbreaks - where do the statistics come from and what do they mean? CDR Review 6, Review 7, 1996; R93-R100

2. Threlfall EJ, Powell NG, Rowe B. Differentiation of salmonellas by molecular methods. PHLS Microbiol Digest 11, 1994; 199-202.

3. Rowe B, Hall MLM. Kauffmann-White Scheme 1989. London. Central Public Health Laboratory 1989

4. Frost JA. Testing for resistance to antibacterial drugs. In: Chart, H. (ed.), Methods in Practical Laboratory Bacteriology. CRC Press, New York 1994; 73-82.

5. Threlfall EJ, Frost JA. The identification, typing and fingerprinting of salmonella: laboratory aspects and epidemiological investigations. J Appl Bacteriol 1990; 68: 5-16.

6. Grimont F, Grimont PAD. Ribosomal ribonucleic acid gene restriction patterns as potential taxonomic tools. Ann Inst Pasteur 1986; 137B: 165-75.

7. Martinetti G, Altwegg M. rRNA gene restriction patterns and plasmid analysis as a tool for typing Salmonella enteritidis. Res Microbiol 1990; 141: 1151-62.

8. Stanley J, Chowdry-Baquar N, Threlfall EJ. Genotypes and phylogenetic relationships of Salmonella typhimurium are defined by molecular fingerprinting of IS200 and $16 \mathrm{~S} \mathrm{rrn}$ loci. J Gen Microbiol 1993; 139: 1133-40.

9. Tompkins LS, Troup N, Labaigne-Roussel A, Cohen ML. Cloned, random chromosomal sequences as probes to identify Salmonella species. J Infect Dis 1986; 152: 156-62.

10. Gibert I, Barbe J, Casadesus J. Distribution of insertion sequence IS200 in Salmonella and Shigella. J Gen Microbiol 1990; 36: 2555-60.

11. Baquar N, Burnens A, Stanley J. Comparative evaluation of molecular typing of strains from a national epidemic due to Salmonella brandenburg by rRNA gene and IS200 probes and pulsed-field gel electrophoresis. J Clin Microbiol 1994; 32: $1876-80$.

12. Pelkonen S, Romppanen E-L, Siitonen A, Pelkonen J. Differentiation of Salmonella serovar infantis from human and animal sources by fingerprinting IS200 and $16 \mathrm{~S}$ rm loci. J Clin Microbiol 1994; 32: 2128-33

13. Threlfall EJ, Torre E, Ward LR, Dvalos-Prez A, Rowe B, Gibert I. Insertion sequence IS200 fingerprinting of Salmonella typhi: an assessment of epidemiological applicability. Epidemiol Infect 1994; 112: 253-61.

14. Thong K-L, Cheong Y-M, Puthucheary S, Koh C-L, Pang T. Epidemiologic analysis of sporadic Salmonella typhi isolates and those from outbreaks by pulsed-field gel electrophoresis. J Clin Microbiol 1994; 32: 1135-41.

15. Threlfall EJ, Hampton MD, Ward LR, Rowe B. Application of pulsed-field gel electrophoresis to an intemational outbreak of Salmonella agona. Emerging Infect Dis 1996; 2: 130-2.

16. Punia P, Ridley AM, Hampton MD, Ward LR, Rowe B, Threlfall EJ. Pulsed-field electrophoretic fingerprinting of Salmonella indiana private and its epidemiological applicability. J Appl Bacteriol, submitted for publication 1997.

17. Powell NG, Threlfall EJ, Chart H, Rowe B. Subdivision of Salmonella enteritidis PT 4 by pulsed-field gel electrophoresis: potential for epidemiological surveillance. FEMS Microbiology Letters 1994; 119: 193-8.

18. Powell NG, Threlfall EJ, Chart H, Schofield SL, Rowe B. Correlation of change in phage type with pulsed-field profile and 16S rrn profile in Salmonella enteritidis phage types 4 , 7 and 9a. Epidemiol Infect 1995; 114: 403-11.

19. Fadl AA, Nguyen AV, Khan MI. Analysis of Salmonella enteritidis isolates by arbitarily primed PCR. J Clin Microbiol 1995; 33: 987-9.

20. Lin AW, Usera MA, Barrett TJ, Goldsby RA. Application of random amplified polymorphic DNA analysis to differentiate strains of Salmonella enteritidis. J Clin Microbiol 1996; 34: 870-6.

21. Hilton AC, Banks JG, Penn CW. Random amplification of polymorphic DNA (RAPD) of Salmonella: strain differentiation and characterisation of amplified sequences. J Appl Bacteriol 1996; 81: 575-84.

22. Stern MJ, Ames GLF, Smith NH, Robinson EC, Higgins CF. Short, interspersed repetitive DNA sequences in prokaryotic genomes. J Bacteriol 1984; 174: 4525-9.

23. Versalovic J, Koeuth T, Lupski JR. private Distribution of repetitive DNA sequences in eubacteria and application to fingerprinting of bacterial genomes. Nucleic Acids Res 1991; 19: 6823-31.

24. MillemannY, Lesages-Descauses M-C, Lafont J-P, ChaslusDancla E. Comparison of random amplified polymorphic DNA analysis and enterobacterial repetitive intergenic consensus-PCR for epidemiological studies of Salmonella. FEMS Immunol. Med Microbiol 1996; 14: 129-34.

25. Public Health Laboratory Service (PHLS), Laboratory of Enteric Pathogens et al. Preliminary report of an international outbreak of Salmonella anatum infection linked to infant formula milk. Eurosurveillance 1997; 2: 22-4 